\title{
ASSESSMENT OF FACTORS INFLUENCING THE ADOPTION OF IMPROVED CROP MANAGEMENT PRACTICES (ICMP) BY SMALLHOLDER FARMERS IN THE BOANE DISTRICT, MOZAMBIQUE
}

\author{
Da Encarnação Tomo, M. ${ }^{1}$ and Zwane, E. ${ }^{2}$
}

Correspondence author: E. Zwane. Email: Elliot.zwane@ul.ac.za

\begin{abstract}
This paper seeks to assess the factors influencing the adoption of the improved crop management practices (ICMP) in Boane District in Mozambique. The study was carried out using a qualitative survey method with a semi-structured interview schedule. Regression analysis and Pearson correlations were used to analyse the factors, constraints, and opportunities influencing the adoption of the improved crop management practices. The study covered a sample of 50 households. The results of the study show that the majority of the farmers (68\%) in the Boane District adopted the improved crop management practices, compared to those who did not adopt them (32\%). According to the logistic regression analysis, two factors (age and access to credit) were significant $(p<0.05)$ at the $5 \%$ level of significance with the adoption of ICMP, meaning that age and access to credit have an influence on the adoption of the improved crop management practices in the Boane District. The study recommended that the Agricultural Development Fund and the district development should solve the challenge of low financial investments, which is the major problem of most smallholder farmers, limiting their response to the production process, and to adopting the improved crop management practices in the Boane District.
\end{abstract}

Keywords: Adoption, Extension, Management practice

\section{INTRODUCTION}

About $80 \%$ of agriculture in Mozambique is mostly based on subsistence farming (Ministéro da Agrucultura, 2010). The agricultural sector in Mozambique engages approximately $80 \%$ of the Mozambican labour force and contributes 34\% of the Gross Domestic Product (GDP). Mozambique's major agricultural products include cotton, cashew nuts, sugarcane, tea, cassava, corn, rice, tropical fruits, beef, and poultry (Ministerio de Agricultura E Seguranca Alimentar (MASA), 2013).

Despite the importance of agriculture, production is at very low levels. This result is due to several factors such as low levels of education, credit accessibility, availability of the extension service, low per capita income, and little investment in production technology (Feder, Just \& Zilberman, 1984). This performance of agriculture is not desirable. Efforts are needed to be implemented in order to increase agricultural productivity. To achieve food security and reduce poverty, it requires a progressive transformation of the agricultural sector from subsistence production to an integrated economy driven by increased agricultural productivity

\footnotetext{
${ }^{1}$ Farm manager, AJAPEMA, Boane District, Maputo, Mozambique, Email: miriantomo@gmail.com

${ }^{2}$ Agricultural Extension Professor, Centre for Rural Community Empowerment, Agricultural Economics and Animal Production, School of Agriculture and Environmental Sciences, Faculty of Science and Agriculture, University of Limpopo, South Africa, Email: Elliot.zwane@ul.ac.za, ORCiD 0000-0002-5933-2910
} 
(International Fertilizer Development Center (IFDC), 2017; Simtowe, Asfaw \& Abate, 2016). Almost everywhere in the world where the process of agricultural transformation has been documented, growth in agricultural productivity is promoted by improved crop management practices (ICMP), including improved seeds, fertilizers, pesticides, irrigation, crop rotation, and efficient use of water resources (Mubai, 2014). In Mozambique, the various agrarian modernisation programmes of the decade 2000 to 2010, such as the National Agrarian Development Programme (PROAGRI), Plan of Action for the Reduction of Absolute Poverty (PARPA), and Green Revolution were not able to promote significant increases in agricultural productivity (Guanziroli \& Guanziroli, 2015). In the current scenario of agricultural production, characterised by the low use of agricultural inputs, productivity in Mozambique ranges between $1 / 5$ and 1/2 of the world's average productivity (Guanziroli \& Guanziroli, 2015).

The identified problem for the purpose of this study is that the adoption of the ICMP in Mozambique is still very low. Less than $5 \%$ of smallholder farmers use fertilizers and pesticides (Uaiene, Arndt \& Masters, 2009). Furthermore, approximately $10 \%$ of the smallholder farmers in Mozambique were reported to be using irrigation practices in 2013 (MASA, 2013). The adoption of the ICMP by farmers depends heavily on the presence of nongovernmental organisations (NGOs), donor-supported projects, or contract farmer programmes, mainly cotton and tobacco crops (Uaiene, 2006), because the government is not in the position to support the farmers appropriately due to a lack of funds. The objectives of this paper are as follows:

- To assess the factors influencing the adoption of improved crop management practices by smallholder farmers in the Boane District, concentrating on conservation agriculture (reduced tillage, crop residues, and crop rotation), fertilizers, pesticides, and irrigation practices.

- To analyse the current level of the adoption of improved crop management practices in Boane District.

- To evaluate the socio-economic and institutional factors influencing adoption of improved crop management practices.

- To identify the opportunities and constraints of maize-legume production based on conservation agriculture in Boane District.

\section{THEORETICAL BACKGROUND}

\subsection{Adoption of improved crop management practices in Mozambique}

There are some promising improved crop management practices in Mozambique. These practices include organic farming, improved field storage techniques, as well as small-scale irrigation methods such as pedestal pumps, fertilizers, intercropping, and residual management (Uaiene, 2011). Unfortunately, these crop management practices are still clearly limited. This translates into low rates of adoption of improved crop management practices (Uaiene, 2011). A possible reason could be that there is a shortage of resources and willingness of farmers to try these innovations.

The low adoption of improved crop management practices is also related to the lack of input credit and lack of product markets (Langyintuo \& Mekuria, 2005; Langyintuo \& Mulugetta, 2008; Uaiene et al, 2009). Uaiene (2006) argued that low product prices do not encourage the 
adoption of improved technologies in the central provinces of Mozambique, and increased profitability involves improved post-harvest storage capacity. This is because many farmers in the family sector participate in the market of products in a very unfavourable manner by selling immediately after the harvest at very low prices. They also return to buy the same products during the time of hunger, but at much higher prices (Arndt \& Tarp, 2000).

An important policy debate focuses on the best ways to promote the adoption of improved crop management practices, but those efforts to promote the adoption of these new agricultural practices have not had major national impact (Filho et al, 2011). In areas with agrarian extension research, some efforts were undertaken to provide credit and training to farmer associations. The results of these efforts will help in the greater commitment to the manner of promoting the crop management practices (Guanziroli \& Guanziroli, 2015). It is hoped that with assistance, smallholder farmers would tend to increase the rate of adoption of ICMP.

External partners in Mozambique had secured an estimated funding of approximately USD 299.1 million to support the horticultural and cereal production programme by 2017 in Mozambique. In essence, this programme was designed to provide three technological packages including intensive use of fertilizers and pesticides, as well as intensive use of the irrigation system. Furthermore, it was planned throughout the project implementation period to conclude contracts with companies specialising in seed quality certification (Da Manhã, 2014).

The smallholder farmers who practice agriculture in Mozambique are in the majority and they are representing $75 \%$ of the total population. Subsistence agriculture is the most practiced farming method by small-scale farmers in a rain-fed system with low levels of ICMP (Silici, Bias \& Cavane, 2015). It is noted in Table 1 that the use of fertilizers and irrigation decreased, and the use of pesticides had a slight growth from 2003 to 2012. According to Cunguara, Garrett and Donovan (2013), there has been no significant progress in the use of agricultural inputs in the last seven years, and Mozambique has one of the lowest rates of fertilizer use in Africa due to the high cost of and poor access to fertilizer. The shortage of fertilizers is partly the result of alleged high import taxes, which is reflected in marketing, even to retailers, as well as the small distribution networks in rural areas, where the majority of the farmers are found. The percentage of farm households using improved crop management is indicated in Table 1.

Table 1: Percentage of farm households using improved crop management practices in Mozambique (2002 - 2012)

\begin{tabular}{|l|l|l|l|l|l|l|l|}
\hline $\begin{array}{l}\text { VARIABLE } \\
\text { DESCRIPTION }\end{array}$ & $\mathbf{2 0 0 2}$ & $\mathbf{2 0 0 3}$ & $\mathbf{2 0 0 5}$ & $\mathbf{2 0 0 6}$ & $\mathbf{2 0 0 7}$ & $\mathbf{2 0 0 8}$ & $\mathbf{2 0 1 2}$ \\
\hline USE OF FERTILIZER (\%) & 3.8 & 2.6 & 3.9 & 4.7 & 4.1 & 4.1 & 2.8 \\
\hline USE OF PESTICIDE (\%) & 6.8 & 5.6 & 5.6 & 5.5 & 4.2 & 3.8 & 6.3 \\
\hline USE OF IRRIGATION (\%) & 10.9 & 6.1 & 6 & 8.4 & 9.9 & 8.8 & 8.1 \\
\hline
\end{tabular}

Source: Silici et al (2015)

The use of fertilizers and pesticides is mainly associated with the production of cash crops such as tobacco and cotton, particularly in the centre and north of Mozambique (Cunguara et al, 2013). Irrigation practice is commonly used by smallholder farmers who are located in areas near the rivers and they have support from the government through the provision of water pumps to their farms (Silici et al, 2015). In general, there is very low pesticide use in 
Mozambique due to financial issues such as a lack of access to credit, lack of incentives and motivation from the government, and limited access to input sellers. Survey results show that only about $6 \%$ of farmers used pesticides in the 2012/2013 agricultural season, and the majority went to tobacco and cotton crops where contract farming prevails (Cachomba et al, 2013). Pesticides can be a valuable tool in modern agriculture, but they are sometimes the cause of the destruction of a company's value (Cachomba et al, 2013). There is, however, a share of rural farmers who make use of modern inputs such as pesticides and fertilizers, although this sector is limited to some regions such as Tete and Zambezia Provinces (Cunguara et al, 2013). It is generally perceived that farmers who use pesticides belong to the higher income groups in rural areas (Guanziroli \& Guanziroli, 2015).

Conservation agriculture has been promoted by a number of development agencies and research organisations since 1996, but the massive adoption of its three principles (minimum disturbance, rotation/intercropping with legumes, and permanent soil cover) remains low. Only two of the principles (intercropping with legumes and permanent soil cover) have been applied by the farmers, but minimum tillage is still a constraint for the smallholder farmers (Grabowski \& Mouzinho, 2013).

There are a number of limitations that lead to non-adoption of conservation agriculture, including limited access to information, lack of credit, farmers' risk aversion, lack of motivation for farmers due to low yields and market issues, lack of mechanisation, inadequate human capital, lack of transport infrastructure, as well as the provision of inputs such as improved seeds, fertilizers, pesticides, and water (Grabowski \& Mouzinho, 2013). Kinyangi (2014) emphasises that the lack of off-farm activities and limited access to credit also influences the risk averse disposition of farmers' perceptions of adopting the new agricultural technologies.

Conservation agriculture practice has its benefits despite the low rates of adoption. Richards et al (2014) argued that conservation agriculture has the potential to improve productivity and thereby contribute to increasing food security and reducing poverty in small-scale production systems in Mozambique. Grabowski and Mouzinho (2013) stated that effective conservation agriculture adoption can be achieved through collaboration amongst stakeholders, institutions, and farmers by carefully monitoring projects for positive results. The Food and Agricultural Organisation of the United Nations upported by Richards et al (2014), stated that other advantages of conservation agriculture practice include improving water and soil quality, reducing environmental degradation, energy efficiency, and improving biodiversity.

\subsection{Factors influencing the adoption of the improved crop management practices}

The adoption of improved crop management practices is influenced by physical, socioeconomic, and institutional factors including agro-ecological conditions, age, family size, family income, education, know-how to knowledge, the source of information, and farmers' attitudes towards the technology (Feder et al, 1984). High levels of adoption of improved maize varieties and chemical fertilizers are more likely to be found amongst farmers situated in regions with high rainfall in Mozambique (Nkala, 2012). Education is projected to enhance the decision-making and the adoption of new technologies. Family size plays a role in labour provision as the adoption of improved crop management practices needs more labour inputs (Souza et al, 2011). 
Sources of information, including extension and knowledge, influences the adoption of improved crop management practices. Farmers who have adequate knowledge of a certain technology use are more likely to adopt it (Rogers, 2003). Farmers' attitudes also determine the adoption of improved crop management practices. Attitudes are evaluative responses towards the technology and are formed as farmers gain information about it. Adopters tend to hold positive attitudes towards the technology (Nkala, 2012).

In general, three paradigms are used to explain adoption behaviour and the determinants of improved crop management practices. These paradigms are: (i) the model of the diffusion of innovation, (ii) the model of the perception of adoption, (iii) the model of economic constraints. The underlying assumption of the innovation diffusion model is that technology is technically and culturally appropriate, but the problem of adoption has to do with asymmetric information and high demand costs (Feder \& Slade, 1984). The second paradigm, the perception of adoption, suggests that the attributes perceived in relation to technology conditions the behaviour of adoption by farmers. This means that, even with complete information on family farming, farmers can subjectively assess technology differently from scientists.

Therefore, understanding the farmers' perceptions of a given technology is crucial for the generation and diffusion of new technologies and dissemination of information about smallholder farms (Feder \& Slade, 1984). The model of economic constraint postulates that the maintenance of short-term inputs such as credit, land, labour, or other important inputs, limits production flexibility and conditions technology adoption decisions. Recent studies have shown that using the three paradigms in modelling technology adoption improves the model's explanatory power relative to a single model (Feder \& Slade, 1984).

\section{METHODOLOGY}

Mozambique is one of the Southern Africa Development Community (SADC) countries and has 10 provinces. The District of Boane is located in the southern region of Mozambique, southwest of Maputo Province, between latitude $26^{\circ} 02^{\prime} 36^{\circ}$ South and longitude $32^{\circ} 19^{\prime} 36^{\circ}$ East. It has a land surface area of $815 \mathrm{~km}^{2}$ and it is bordered to the north by the Moamba District, to the south by the Namaacha District, to the east by the City of Matola and the District of Matutuine, and to the west by the District of Namaacha (Figure 3). The district is divided into two administrative posts, namely Boane-Sede, where most of the population resides and includes the localities of Gueguegue, Eduardo Mondlane, and the Administrative Post of Matola-Rio with a locality of the same name (Matola rio) (Ministério Da Administração Estatal (MAE), 2005).

\subsection{Research design}

The study was carried out through a predominantly qualitative survey, based on a semistructured interview schedule. The survey was aimed to identify the status of improved crop management practices, to determine the factors influencing the adoption of improved crop management practices, and to determine the farmers' constraints and opportunities to adopt conservation agriculture in the Boane District. The interviews were carried out in five villages considered to be representative of the whole population since they had a larger number of farmers in the Boane District. The villages included Massaca, 25 de Setembro, Mavoco, Picoco, and Mahubo. Therefore, the unit of analysis were the rural smallholder farmers which operates as the ultimate decision-making unit in farming and livelihood process. 
The data collected were essentially primary, collected directly from the category questionnaires and interviews. The survey was administered in five villages, where 10 respondents were randomly selected from each village. The data collection process lasted two weeks, where the visits to each village lasted approximately two days in order to cover the 10 participants in each village. Data was obtained from the interviews conducted with the technicians of district economic services in order to cross-check their information with that which would be provided by the farmers. The questionnaire consisted of 37 questions organised into eight sections.

\subsection{Data analysis and interpretation}

The computer software programme for statistical analysis, the Statistical Package for Social Sciences (SPSS, version 22), was used to analyse all the data, including descriptive statistics, logistic regression (Logit model), and Pearson correlations. The Logit model was used to assess the factors influencing the adoption of improved crop management practices. Pearson's correlation was used to analyse the association between constraints and opportunities with the adoption of conservation agriculture.

\section{RESULTS AND DISCUSSION}

\subsection{Demographic characteristics of the respondents}

It was verified that women are more likely to adopt ICMP as compared to men. Farmers who adopt ICMP were adults in the age category of 46-65 years. The higher the level of education, the lower the level of adoption of ICMP. The majority of the respondents who adopted ICMP were constituted by 6-10 household members. Associated farmers are more likely to adopt ICMP than non-associated farmers. Furthermore, the more farming time experience, the greater the adoption of ICMP. Finally, farmers with high income and large farms are more likely to adopt ICMP.

\subsection{The current level of adoption of the ICMP by smallholder farmers in Boane District}

The majority of the farmers (68\%) in the Boane District adopted ICMP compared to those who did not adopt (32\%). This result is due to the great government effort to encourage smallholder farmers to organise themselves into associations and later to assist them in the provision of inputs, knowledge, and technical skills. In addition to the help of extension agents to increase ICMP adoption, the majority of the adopters $(64.7 \%)$ had received information about ICMP through other farmer experiences, and this is another reason for the improvement of the adoption of ICMP in the Boane District. Jorge (2013), in his study on the adoption of new agricultural technologies in the Boane District, found that $56 \%$ of the farmers adopted the new technologies, and 44\% did not adopt ICMP. Therefore, there is an increase of $12 \%$ in the adoption of ICMP in the Boane District from 2013 to 2017.

The study was carried out in five villages (25 de Septembro, Picoco, Massaca, Mavoco, and Mahubo). The majority of the adopters belong to Mahubo (26.5\%) and 25 de Septembro $(23.5 \%)$ villages. The fewest number of adopters belong to Massaca (17.6\%), Mavoco (17.6\%), and Picoco (14.7\%). 


\subsection{Socio-economic and institutional factors influencing the adoption of the improved crop management practices in the Boane District}

According to the logistic regression analysis (Table 2), two factors (age and access to credit) were significant $(\mathrm{p}<0.05)$ at the $5 \%$ level of significance with the adoption of ICMP, meaning that these factors have a significant influence on the adoption of ICMP in Boane District. Gender, level of education, farming time, household number, off-farm income, land tenure, farm size, farmers' group, information about ICMP, and extension services were not found to be statistically significant, meaning that they were not significant in influencing the adoption of ICMP. This means that the extension agents may not be doing the work effectively to the point of not influencing the adoption of the ICMP significantly given the poor working conditions in which they work. The results of the logistic regression analysis is portrayed in Table 2.

Table 2: Logistic regression analysis of the factors influencing the ICMP adoption by the smallholder farmers in the Boane District

\begin{tabular}{|c|c|c|}
\hline \multicolumn{3}{|l|}{ Variables in the Equation } \\
\hline Independent Variable & Estimated Parameters ( $\beta \mathrm{i})$ & P value \\
\hline Gender & 1.723 & $.316(\mathrm{~ns})$ \\
\hline Age & 2.191 & $.005^{*}$ \\
\hline Level of education & -1.883 & $.113(\mathrm{~ns})$ \\
\hline Farming time & -1.706 & $.179(\mathrm{~ns})$ \\
\hline Household size & 177 & $.834(\mathrm{~ns})$ \\
\hline Access to credit & 5.868 & $.047 *$ \\
\hline Off-farm income & -.655 & $.574(\mathrm{~ns})$ \\
\hline Land ownership & -3.162 & $.077(\mathrm{~ns})$ \\
\hline Farm size & .000 & $.060(\mathrm{~ns})$ \\
\hline Membership farmers' group & -19.056 & $.999(\mathrm{~ns})$ \\
\hline Information about ICMP & -1.676 & $.204(\mathrm{~ns})$ \\
\hline Extension services & 22.632 & $.999(\mathrm{~ns})$ \\
\hline Constant & 12.501 & $.167(\mathrm{~ns})$ \\
\hline Nagelkerke $\mathbf{R}$ square & $60.8 \%$ & \\
\hline Cox \& snell R square & $43.4 \%$ & \\
\hline
\end{tabular}

Sig $=5 \%$ level of significance: $*$ (significant $) ; \mathrm{ns}=$ not significant

The adjusted $\mathrm{R}^{2}$ of the regression was 0.608 , which means that $60.8 \%$ of the dependent variable can be explained by the regressors present in the model. The higher the $\mathrm{R}^{2}$, the more explanatory the model is, and the better it fits the sample.

Off-farm income, information about ICMP, membership farmers' group, and farming time were negatively significant. Therefore, they have no influence on the adoption of ICMP, and an increase in all those variables decreases the chance to adopt the ICMP. While farm size was also not significant, but the relation was positive, this means that an increase in the farm size will increase the chance of adopting the ICMP. The age variable obtained a high positive coefficient and was statistically significant at the 5\% level of significance of the econometric 
model equation, showing its relevance for the adoption of ICMP. In other words, as the age of the farmer increases, the farmer becomes more susceptible to adopting ICMP. This result is in contradiction to Langyintuo and Mulugetta (2008), Mubai (2014), as well as Zavale, Mabaya and Christy (2005) who all stated that the younger the age, the greater the probability of adopting the new agricultural technologies.

However, other authors, Buainain et al (2007) and Filho et al (2011), concluded that the increase in age would increase the crystallised intelligence and, therefore, the probability of adopting a certain agricultural technology. According to the descriptive statistics of this research in relation to age, it shows that half of the adopters were between the age of 45 and 50 years, supporting this result which indicates that the higher the age, the greater the adoption.

Filho et al (2011) had an explanation regarding the positive significance of age. He argued that although older farmers find it difficult to obtain information on new technologies, thus reducing their exposure to it, they are quicker to adopt new technologies because they have a greater allocation of resources than the young. This observation complements the paradigm on economic retractions explained by Feder and Slade (1984), as it is assumed that older farmers can adopt ICMP and young people are less likely to adopt because of economic restriction. According to the logistic regression results, the credit variable was significantly positive in relation to the adoption of ICMP, and it appears to have the highest coefficient at the logistic model equation, meaning that the influence this factor has on the adoption is very strong. In other words, the greater the access to credit, the greater the adoption of ICMP, and farmers with no access to credit may not be able to adopt ICMP.

Makundi (2008) found the same result and argued that farmers who have no access to credit have a constraint to adopt ICMP such as irrigation and pesticides as they are very expensive. Serman and Filson (1999) said that the availability of credit by the farmers improves the capacity to adopt the new technology, as they have the required capital to start practicing the new agricultural technologies. According to Guanziroli and Guanziroli (2015), if the increase in resources is encouraged (via credit, for example), there may be increases in adoption of ICMP due to access of credit.

\subsection{Opportunities and constraints}

\subsubsection{Opportunities}

According to the Pearson correlation, one variable was significant, that is, improved soil fertility had a positive correlation with the adoption of conservation agriculture. More of these opportunities are reflected in Table 3.

According to $82 \%$ of the respondents, the conservation agriculture practice can increase soil fertility by adding organic material into the soil through crop residues. Most of the respondents said that they leave the remains of crops in the soil to incorporate organic matter. Cardoso et al (2014) argued that soil fertility is directly linked to the presence of organic matter in the soil. Soil organic matter plays a fundamental role in the maintenance of soil functions, given its influence on soil structure and stability, water retention, biodiversity, and as a source of nutrients for plants. 
Table 3: Opportunities of conservation agriculture based on maize-legume production (Pearson correlation test)

\begin{tabular}{|l|l|l|}
\hline Variable & Pearson correlation & P-value \\
\hline Yield increase & -065 & $0.651(\mathrm{~ns})$ \\
\hline Improving water and soil quality & -019 & $0.897(\mathrm{~ns})$ \\
\hline Improved soil fertility & +125 & $0.042 *$ \\
\hline Improved HH food security & +044 & $0.754(\mathrm{~ns})$ \\
\hline Labour saving & -068 & $0.631(\mathrm{~ns})$ \\
\hline
\end{tabular}

Sig $=5 \%$ level of significance: $*$ (significant $) ; \mathrm{ns}=$ not significant

\subsubsection{Constraints}

Regarding the constraints, the Pearson correlation test showed that three variables were significant, that is, poor rainfall pattern, shortage of inputs, and limited capital had a positive correlation with the adoption of conservation agriculture in the Boane District. Some of the constraints are indicated in Table 4.

Table 4: Constraints of conservation agriculture based on maize-legume production (Pearson correlation test)

\begin{tabular}{|l|l|l|}
\hline Variable & Pearson correlation & P-value \\
\hline Limited capital & +926 & $0.013 *$ \\
\hline Extreme temperature & +210 & $0.114(\mathrm{~ns})$ \\
\hline Limited access to land & -098 & $0.497(\mathrm{~ns})$ \\
\hline Security land tenure & +153 & $0.288(\mathrm{~ns})$ \\
\hline Shortage of inputs & +013 & $0.025 *$ \\
\hline $\begin{array}{l}\text { Limited access to extension } \\
\text { services }\end{array}$ & -016 & $0.921(\mathrm{~ns})$ \\
\hline Afraid of taking risk & -125 & $0.387(\mathrm{~ns})$ \\
\hline Poor rainfall patterns & +924 & $0.015 *$ \\
\hline
\end{tabular}

Sig $=5 \%$ level of significance: $*$ (significant); ns = not significant

Limited capital and shortage of inputs were positively significant, meaning that the correlation between these variable and the adoption of conservation agriculture is strong (Table 4). This result is in line with the study conducted by Bhan and Behera (2014) on conservation agriculture in India which stated that the lack of inputs, especially for smallholder farmers, impeded the adoption of conservation agriculture on a broad scale. Parks, Christie and Bagares (2014) also found that limited capital is a large constraint for conservation agriculture which affects its adoption. It was further noted that if there is a lack of capital then any conservation measure is unlikely to be adopted (Parks, Christie \& Bagares, 2014).

\section{CONCLUSION AND RECOMMENDATIONS}

The level of ICMP in the Boane District is growing with each passing year. The majority of the farmers $(68 \%)$ in the Boane district have adopted ICMP. There was an increase of $12 \%$ in the adoption of ICMP in the Boane District from 2013 to 2017. The major reason why the respondents have adopted ICMP is due to the increase of yield. Those who have not adopted ICMP explained that it is because they are used to practicing the conventional agricultural 
methods, and because there is a shortage of inputs. Nevertheless, the increase in the level of ICMP adoption will consequently increase the agricultural productivity in the Boane District. According to the statistical analysis (logistic regression), age and access to credit factors had a positive and significant influence on the adoption of ICMP. That is, the age and access to credit factors influence the adoption of ICMP. This indicates that an increase in age or credit can increase the chances of adopting ICMP in the Boane District. The other factors such as gender, level of education, farming time, household number, off-farm income, land tenure, farm size, farmers' group, information about ICMP, and extension services were not significant to influence the adoption of the ICMP, meaning that these factors do not influence the adoption of the improved crop management practices.

The opportunities and constraints faced by smallholder farmers to adopt conservation agriculture are various. However, according to the Pearson correlation test, only improved soil, limited capital, poor rainfall patterns, and shortage of inputs were positively significant. It is concluded that there is a correlation between improved soil, limited capital, poor rainfall patterns, and shortage of inputs and the adoption of conservation agriculture. That is, they are strongly correlated to the adoption of conservation agriculture under maize-legumes production.

Based on the findings of the paper, the following recommendations can be made:

- Income and financial capital are important elements in the adoption of ICMP, thus, efforts need to be made to advise farmers to have other sources of income, apart from agrarian activity, such as small businesses in order to overcome the issue of a lack of capital and to increase their income.

- It is necessary for the Public Agricultural Extension Programme to advance in its policy and adjust the focus to the real needs of the smallholder farmers according to the factors and constraints that influence the adoption of ICMP, as in the collective strategies of the families, in the promotion of their small economic and productive activities, incentives for food production, and financing to farmers who strengthen the basic production unit in the Boane District.

\section{REFERENCES}

ARNDT, C. \& TARP, F., 2000. Agricultural technology, risk, and gender: A CGE analysis of Mozambique. World Dev., 28(7):1307-1326.

BHAN, S. \& BEHERA, U.K., 2014. Conservation agriculture in India - Problems, prospects and policy issues. Int. Soil Water Conserv. Res., 2(4):1-12.

BUAINAIN, A.M., DE SOUZA FILO, H.M., GUANZIROLI, C. \& BATALHA, M.O., 2007. Agricultura familiar e tecnologia no Brasil: Características, desafios e obstáculos [Familiar agriculture and technology in Brazil: Characteristics, challenges and obstacles]. Available from: http://www.sober.org.br/palestra/12/090442.pdf

CACHOMBA, I., CAIRNS, J., TSCHIRLEY, D. \& SNYDER, J., 2013. Percepção de risco e comportamento no uso dos pesticidas pelos produtores de hortícolas de Maputo [Perception of risk and behaviour in the use of pesticides by Maputo horticultural producers]. Available from: fsg.afre.msu.edu/mozambique/flash/Flash_69P.pdf

CARDOSO, R.A., BENTO, A.S., MORESKI, H.M. \& GASPAROTTO, F., 2014. Influência da adubação verde nas propriedades físicas e biológicas do solo e na produtividade da 
cultura de soja [Influence of green fertilization on soil physical and biological properties and soybean crop productivity]. Available from: https://doi.org/10.5433/1679$\underline{0367.2014 v 35 \mathrm{n} 2 \mathrm{p} 51}$

CUNGUARA, B., GARRETT, J. \& DONOVAN, C., 2013. Análise situacional, constrangimentos e oportunidades para o crescimento agrário em Moçambique [Situational analysis, constraints and opportunities for agrarian growth in Mozambique]. Report No. 1093-2016-87895. Maputo, Mozambique.

DA MANHÃ, C., 2014. Disponiveis UDS299.1 milhões para seguranca alimentar [Available UDS299.1 million for food safety]. Available from: http://www.verdade.co.mz/economia/44047-disponiveis-uds-2991-milhoes-paraseguranca-alimentar

FEDER, G. \& SLADE, R., 1984. Information acquisition and the adoption of new technology. Am. J. Agric. Econ., 66(3):312-320.

FEDER, G., JUST, R.E. \& ZILBERMAN, D., 1984. Adoption of agricultural innovations in developing countries: A survey. Econ. Dev. Cult. Change, 33(2):255-298.

FILHO, H.M., BUAINAIN, A.M., DA SILVEIRA, J.M.F.J. \& VINHOLIS, M.M.B., 2011. Condicionantes da adoção de inovações tecnológicas na agricultura [Constraints on the adoption of technological innovations in agriculture]. Available from: https://seer.sct.embrapa.br/index.php/cct/article/view/12041

GRABOWSKI, P. \& MOUZINHO, B., 2013. Priorização de ações para agricultura de conservação em Moçambique [Prioritisation of conservation agriculture actions in Mozambique]. Available from: fsg.afre.msu.edu/mozambique/WP5P_v4.pdf

GUANZIROLI, C.E. \& GUANZIROLI, T., 2015. Modernização da agricultura em Moçambique: Determinantes da renda agrícola [Modernisation of agriculture in Mozambique: Determinants of agricultural income]. Available from: https://doi.org/10.1590/1234-56781806-94790053s01009

INTERNATIONAL FERTILIZER DEVELOPMENT CENTER (IFDC), 2017. Promoting agriculture technology to improve productivity and net returns for smallholder farmers. Available from: https://ifdc.org/promoting-agriculture-technology-to-improveproductivity-and-net-returns-for-smallholder-farmers/

JORGE, A.A., 2013. Impacto do fundo de investimento local na adopção de tecnologias agrárias: Caso do distrito de Boane (2006-2011) [Impact of local investment fund on the adoption of agrarian technologies: Boane District case (2006-2011)]. Available from http://www.repositorio.uem.mz/bitstream/123456789/209/1/2013\%20\%20Jorge\%2C\%20Ars\%C3\%A9nio\%20Ar\%C3\%A3o.pdf

KINYANGI, A.A., 2014. Factors influencing the adoption of agricultural technology among smallholder farmers in Kakamega north sub-county, Kenya. Available from: http://erepository.uonbi.ac.ke/bitstream/handle/11295/76086/Kinyangi_Factors\%25\%0 920influencing the adoption of agricultural technology amo\%09ng smallholder farmers .pdf?sequence $=1$

LANGYINTUO, A.S. \& MEKURIA, M., 2005. Accounting for neighborhood influence in estimating factors determining the adoption of improved agricultural technologies. Available from: https://ageconsearch.umn.edu/bitstream/19521/1/sp05la03.pdf\%0A

LANGYINTUO, A. \& MULUGETTA, M., 2008. Assessing the influence of neighborhood 
effects on the adoption of improved agricultural technologies in developing agriculture. Afr. J. Agr. Resour. Econ., 2(2):151-169.

MAKUNDI, J.S., 2008. Assessment of factors affecting adoption of land management technologies in Tanga district. Master's Thesis, Sokoine University of Agriculture.

MINISTÉRIO DA ADMINISTRAÇÃO ESTATAL (MAE), 2005. Perfil do distrito de Boane província de Maputo [Profile of the district of Boane, Maputo province]. Available from: www.portaldogoverno.gov.mz/por/content/download/2965/23877/version/.../Boane.pdf

MINISTÈRO DA AGRICULTURA, 2010. Plano Estrategico Para o Desenvolvimiento do Sector Agrário (PEDSA). Available from: https://docplayer.com.br/9655218-Planoestrategico-para-o-desenvolvimento-do-sector-agrario-pedsa-2011-2020.html

MINISTERIO DE AGRICULTURA E SEGURANCA ALIMENTAR (MASA), 2013. Estrategia de Irrigacao [Irrigation strategy]. Available from: www.inir.gov.mz/files/2014-07/Estrategia de Irrigacao.pdf\%0A

MUBAI, B.A., 2014. A extensão agrícola públic e o apoio ao desenvolvimento da pequena agricultura familiar do distrito de Boane-Moçambique [The agricultural public extension and its development support regarded to small families agriculture related to the district of Boane, Mozambique]. Agrária, 9:19.

NKALA, P., 2012. Assessing the impacts of conservation agriculture on farmer livelihoods in three selected communities in central Mozambique. Available from: http://www.boku.ac.at/fileadmin/data/H04000/H16900/Resources/Scientific_Pub/Peter _Nkala_2012_.pdf

PARKS, M.H., CHRISTIE, M.E. \& BAGARES, I., 2014. Gender and conservation agriculture: Constraints and opportunities in the Philippines. GeoJournal, 80(1):61-77.

RICHARDS, M., SAPKOTA, T., STIRLING, C., THIERFELDER, C., VERHULST, N., FRIEDRICH, T. \& KIENZLE, J., 2014. Conservation agriculture: Implementation guidance for policymakers and investors. Available from: http://www.fao.org/3/ai4066e.pdf

ROGERS, E.M., 2003. Diffusion of innovations. $4^{\text {th }}$ ed. New York: Free Press.

SERMAN, N. \& FILSON, G.C., 1999. Factors affecting farmers' adoption of soil and water conservation practices in Southwestern Ontario. Available from: https://www.uoguelph.ca/ gfilson/southwestern.html

SILICI, L., BIAS, C. \& CAVANE, E., 2015. Sustainable agriculture for small-scale farmers in Mozambique. IIED Country Report. London, United Kingdom.

SIMTOWE, F., ASFAW, S. \& ABATE, T., 2016. Determinants of agricultural technology adoption under partial population awareness: The case of pigeonpea in Malawi. Agric. Food Econ., 4(7):1-21.

SOUZA, H.M., BUAINAIN, A.M., SILVEIRA, J.M.F.J. \& VINHOLIS, M.M.B., 2011. Condicionantes da adoção de inovações tecnológicas na agricultura [Conditional factors of adoption of technological innovations in agriculture]. Available from: http://seer.sct.embrapa.br/index.php/cct/article/view/12041

UAIENE, R.N., 2006. Moçambique Direcção de Formação, Documentação e Transferência de Tecnologias. [Mozambique Directorate of Training, Documentation and Transfer of Technologies]. IIAM Relatório de Pesquisa No. 2. Maputo, Mozambique. 
S. Afr. J. Agric. Ext.

Vol. 48 No. 1, 2020: 99 - 111

http://dx.doi.org/10.17159/2413-3221/2020/v48n1a529
Da Encarnação Tomo

\& Zwane

(License: CC BY 4.0)

UAIENE, R.N., 2011. Determinantes para a Adopção de Tecnologias Agrícolas em Moçambique [Determinants for the Adoption of Agricultural Technologies in Mozambique]. Available from: http://fsg.afre.msu.edu/Mozambique/caadp/Uaiene_Adopcao_Tecnologias_Pt.pdf

UAIENE, R., ARNDT, C. \& MASTERS, W., 2009. Determinants of agricultural technology adoption in Mozambique. Available from http://196.46.4.208/gest/documents/67E_AgTechAdoptionMoz.pdf

ZAVALE, H., MABAYA, E. \& CHRISTY, R., 2005. Adoption of improved maize seed by smallholder farmers in Mozambique. Available from. http://www.econstor.eu/handle/10419/58234 
